\title{
FIRST RECORD OF Cylindroiulus horvathi (DIPLOPODA, JULIDA, JULIDAE) IN SERBIA
}

\author{
Zvezdana S. Jovanovič* and Dragan Ž. Antić \\ Institute of Zoology, Faculty of Biology, University of Belgrade, Studentski Trg 16, \\ 11000 Belgrade, Republic of Serbia \\ *E-mail: z.jovanovic.bio@gmail.com
}

(Received March 6, 2015)

\begin{abstract}
Cylindroiulus horvathi (Verhoeff, 1897), found at a single locality in Vojvodina, north Serbia, is the third representative of the genus Cylindroiulus Verhoeff, 1894 in Serbian millipede fauna. Brief description and ecological aspects are given. Key to the Cylindroiulus species in Serbia and distribution map with incorporated new data are also provided.
\end{abstract}

Key words: Serbia, Diplopoda, Julida, Cylindroiulus.

\section{INTRODUCTION}

Currently, the Serbian millipede fauna includes 101 species, belonging to 44 genera and 16 families of which Julidae, with 16 genera and 41 species, is the largest (ANTIC et al., 2013, 2014). Although the genus Cylindroiulus Verhoeff, 1894 includes about 100 species in Europe (Enghoff and Kime, 2013), only two of them were registered in Serbia up to now: Cylindroiulus boleti (C. L. Koch, 1847) and C. luridus (C. L. Koch, 1847) (ANTIĆ et al., 2013). C. horvathi (Verhoeff, 1897) is the third species of this genus and the 102. species of millipedes in Serbia. It belongs to the horvathi group of species, alongside Cylindroiulus abaligetanus Verhoeff, 1901 and C. cambio Korsós \& Read, 1994. Similarities in external characteristics and in gonopod structure have been recognized (ATTEMS, 1903; VERHOEFF, 1905), which led to the establishment of the group. They are small animals, with a crenulated limbus and an indented apex of the gonopodal opisthomerite, separating the brachite from the solenomerite. Their distribution area extends from the middle Europe, Balkan Peninsula, Crimea, to northwest Russia (KoRSÓs and READ, 1994). This paper represents the first report of $C$. horvathi in Serbia.

\section{MATERIAL AND METHODS}

Specimens were preserved in $70 \%$ ethanol and analyzed at the laboratories of the Institute of Zoology, University of Belgrade - Faculty of Biology. Examination of the whole specimens was done using a Carl Zeiss Stemi 2000-c binocular stereomicroscope with an AxioCamMRc camera and AxioVision Rel. 4.2 program. For adult specimens, dimensions 
and numbers of body rings were determined. Photographs of the gonopods were prepared on Carl Zeiss Axioscope 40 microscope with Canon PowerShot A80 digital camera connected and processed through Zerene Stacker program.

To illustrate the distribution of the genus Cylindroiulus in Serbia we used the UTM notation system. The map records the presence of the species in $10 \mathrm{~km}$ squares of the UTM grid. The map (Fig. 4) records the presence of the species in $10 \mathrm{~km}$ squares of the UTM grid.

\section{RESULTS AND DISCUSSION}

Cylindroiulus horvathi (Verhoeff, 1897) (Figs. 1 and 3)

Syns.: Cylindroiulus vitosae Strasser, 1962

Cylindroiulus dietli Verhoeff, 1989

Cylindroiulus ponticus Golovatch, 1978

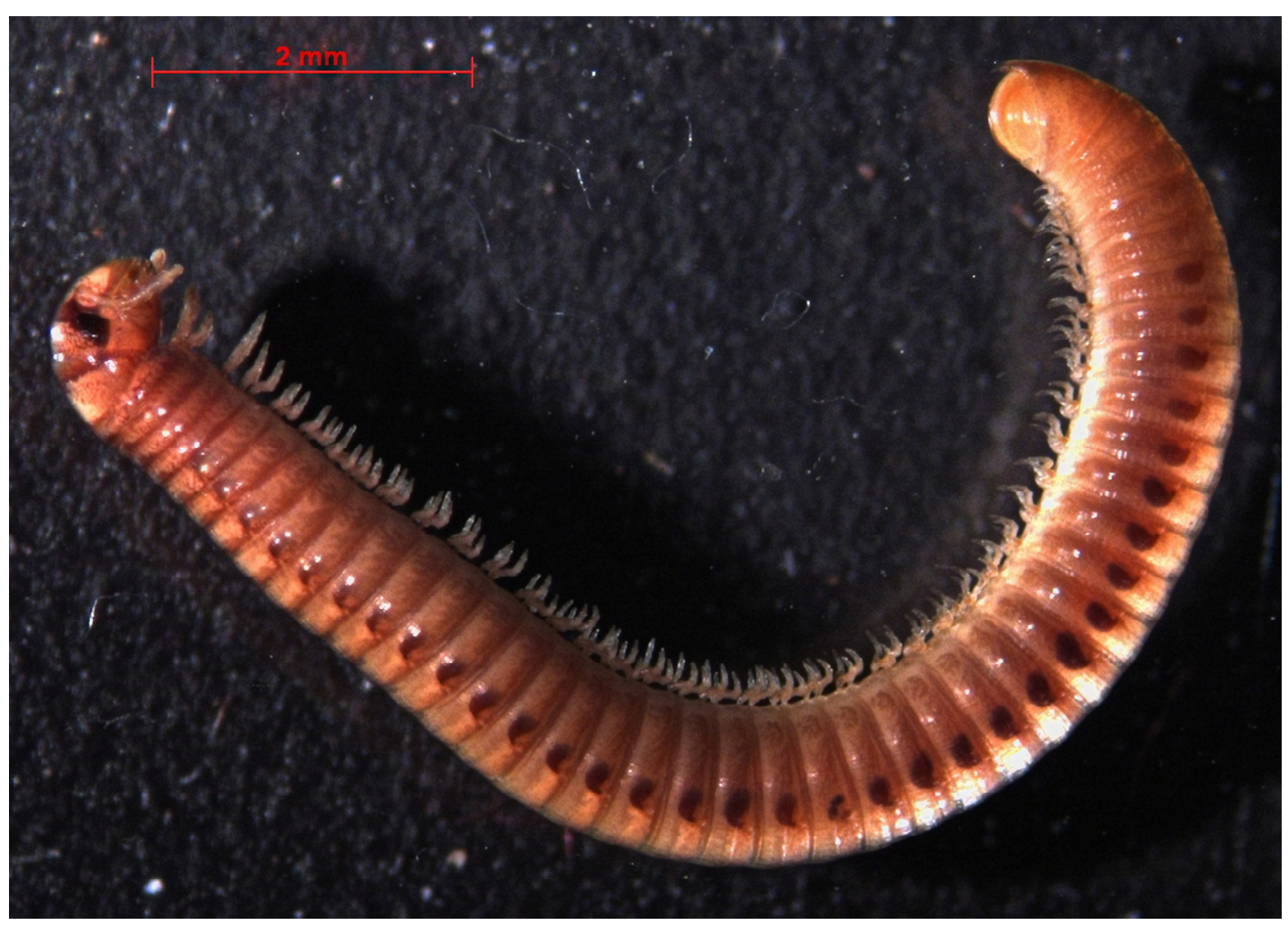

Fig. 1. Cylindroiulus horvathi (Verhoeff, 1897), a female from the shores of Lake Rusanda, Vojvodina, Serbia.

Material examined: 1 female, 1 male and a juvenile specimen from the shores of Lake Rusanda (Fig. 2), near Melenci, Vojvodina, north Serbia, collected on 3/18/2014, by M. Šćiban. Specimens are kept at the Institute of Zoology, University of Belgrade - Faculty of Biology.

Short description: Female with 43 body rings + telson, length $11.5 \mathrm{~mm}$, maximum height $1.10 \mathrm{~mm}$. Male with 40 body rings + telson, length $9.3 \mathrm{~mm}$, maximum height $0.8 \mathrm{~mm}$. Coloration light yellowish brown with distinctive ozadenes and lighter legs. Darker middorsal stripe present. Head with antennae reaching first trunk body ring. Telson with an epiproctal projection directed downward. Gonopods: promerite and mesomerite of equal length. Projecting rim of promerite enwrapping mesomerite laterally. Oral margin of 
mesomerite indented. Paracoxal rim prominent, embowed. Paracoxal process wide, blunt, with notches on posterior margin. Solenomerite projecting beyond tip of brachite (Fig. 3).

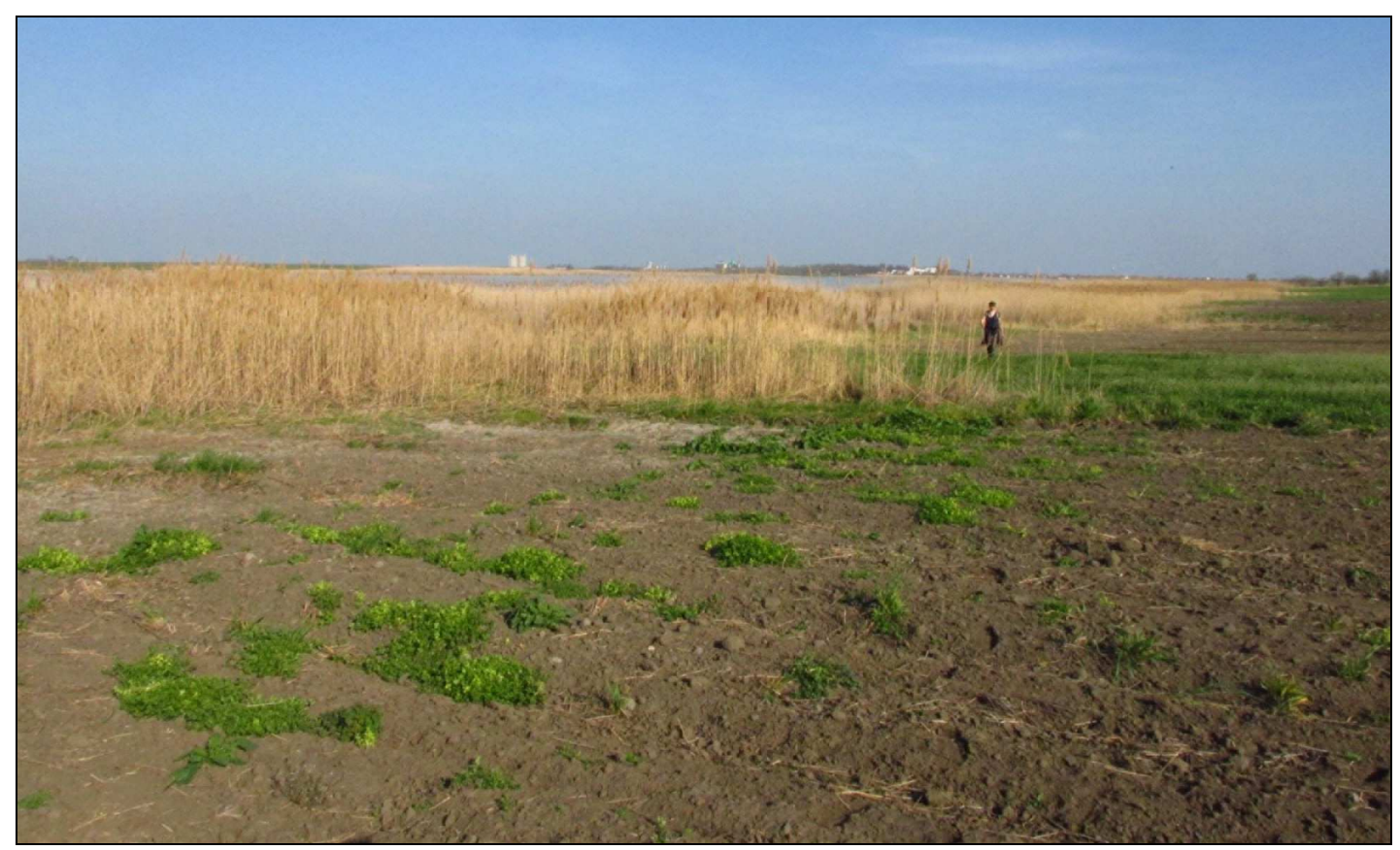

Fig. 2. Shore of Lake Rusanda, habitat of Cylindroiulus horvathi (Verhoeff, 1897) in Serbia (photo M. Šćiban).

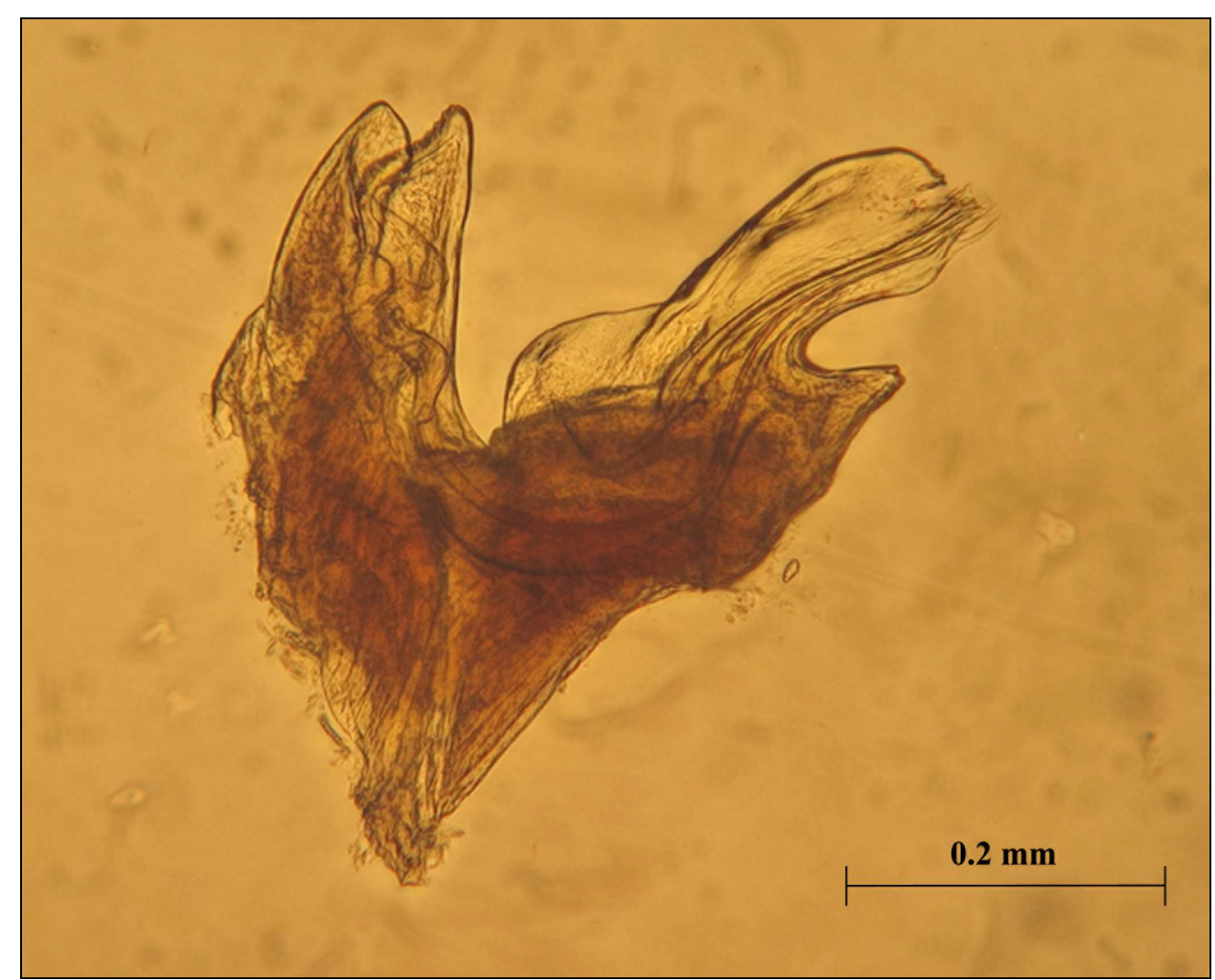

Fig. 3. - Cylindroiulus horvathi (Verhoeff, 1897), gonopods, mesal view, male from the shores of Lake Rusanda, Vojvodina, Serbia. 
Distribution: The distribution area of $C$. horvathi ranges from Poland in the north across Hungary and Romania to Bulgaria in the south. The eastern-most find of this species is in Crimea (KORSÓs and READ, 1994). Considering that this species has been reported in a few neighbouring countries, its presence in Serbia had been expected.

Ecology: This species is known to inhabit xeric environments such as dry grassland and steppe vegetation (KORSÓS and READ, 1994). These habitats are present in the northern part of Serbia, where the single known locality of this species is located. All three specimens were collected on a sunny day on the dry land on the shores of the lake.

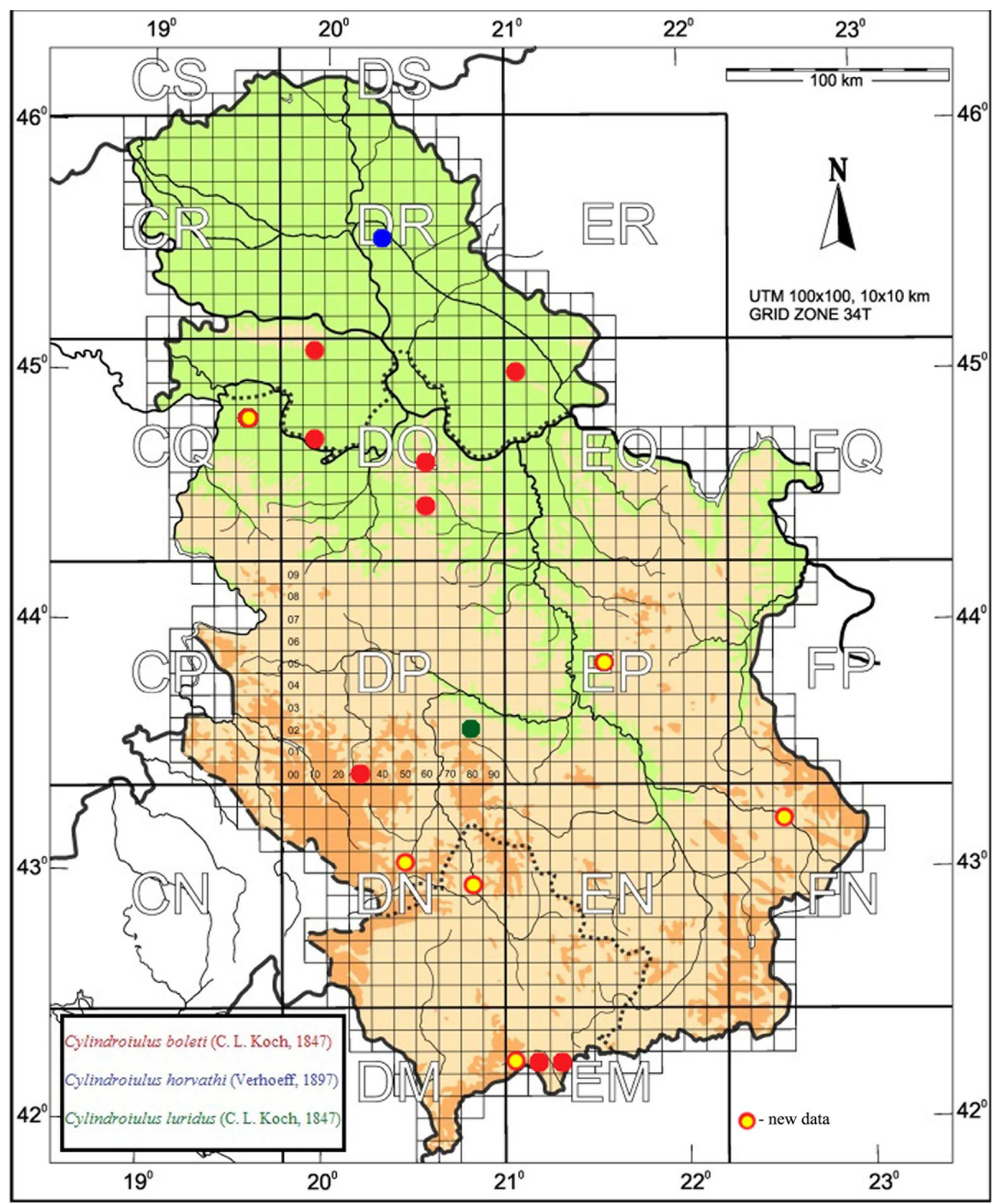

Fig. 4. Distribution map of Cylindroiulus species in Serbia. 


\section{Distribution of Cylindroiulus species in Serbia (Fig. 4):}

Cylindroiulus boleti (C. L. Koch, 1847): Deliblatska peščara (VUČKOVIĆ, 1956); v. Gledjica, near Ivanjica (ĆURČIĆ and MAKAROV, 1998); Ljuboten, Mt. Šar planina (ATTEMS, 1929); Kačanik (VučKović, 1956); Mt. Fruška Gora (VučKoviĆ, 1956); Mt. Kosmaj (VučKoviĆ, 1956); north and central Serbia (ĆURČIĆ and MAKAROV, 1997); Obedska Bara, v. Obrež, nr. Belgrade (MAKAROV et al., 2004); Ripanj, nr. Belgrade (MAKAROV et al., 2004); without precise locality (STRASSER, 1971, 1971a; MRŠIĆ, 1985) east Serbia (ANTIĆ et al., 2013);

new data: 3 males, 1 female, 1 juvenile, v. Temska, Pirot, 6/1/2011, 6/2/2011, leg. D. Antić; 3 females, v. Izbice, Novi Pazar, 2012. leg., D. Stojanović; 1 male and 1 female, v. Viče, Mt. Šar planina, 5/11/2012, leg. N. Živić; 1 male, Leposavić, Zrnosek, 10/17/2012, leg. N. Živić; 1 female, vrelo Grze, Paraćin, 7/9/2009, leg. D. Antić and D. Stojanović; 2 juveniles, r. Ivanštica, Grza, Paraćin, 7/12/2009, leg. J. Đuknić; 1 female, klisura Ivanštice, Grza, Paraćin, 4/19/2010, leg. J. Đuknić; 1 juvenile, planinarski dom, Grza, Paraćin, 4/19/2010, leg. D. Antić; 6 females and 3 males, planinarski dom, Grza, Paraćin, 4/22/2010, leg. BID "Josif Pančić"; 1 female, planinarski dom, Grza, Paraćin, 7/8/2010, leg. D. Antić; 3 females and 1 juvenile, Donje jezero, Grza, Paraćin, 7/10/2010, leg. BID "Josif Pančić”; 1 female, Ravlje, Staniševac, Zasavica, Sremska Mitrovica, 8/5/2009, leg. M. Stanković; 1 female, Turske livade, Zasavica, Sremska Mitrovica, 11/18/2011, leg. M. Stanković; 1 female, Trebljevine, Banovo Polje, Zasavica, Sremska Mitrovica, 8/5/2012, leg. M. Stanković; 1 male and 1 female, Šumareva Ćuprija, Zasavica, Sremska Mitrovica, 4/23/2013, leg. M. Šćiban.

Cylindroiulus horvathi (Verhoeff, 1897): Rusanda Lake, nr. Melenci (present study).

Cylindroiulus luridus (C. L. Koch, 1847): Central Serbia (ĆURČIĆ and MAKAROV, 1997); Donji Jasmići, Mt. Goč (MrŠIĆ, 1985).

\section{Key to the identification of Cylindroiulus species in Serbia:}

Description of the genus Cylindroiulus: Without frontal setae and setae on the metazonites. Flagellum always present. Brachite narrow. Coxite rising laterally as a high, semi-circular hump. Promerite and mesomerite short. Opisthomerite inclined backward (SCHUBART, 1934; READ, 2007).

1. Telson with downward directed epiproctal projection

Without projection of telson beyond anal valves

..................

......Cylindroiulus boleti

2. Promerite and mesomerite subequal in length. Brachit well developed and wide, separated by a small indentation from solenomerite.

....Cylindroiulus horvathi

Promerite and mesomerite short and broad, with mesomerite somewhat shorter than promerite. Opisthomerite with narrow, curved hook-shaped brachite.

..... Cylindroiulus luridus

\section{Acknowledgments}

This work was supported by the Serbian Ministry of Education, Science, and Technology (Grant 173038). The authors are grateful to all collectors who sent Cylindroiulus 
samples considered in this study. Marko Šćiban kindly provided a photo of habitat of $C$. horvathi.

\section{References:}

[1] AnTiĆ, D.Ž., ĆurČić, B.P.M., Tomić, V.T., ĆurČIĆ, S.B., STOJANOvić, D.Z., Dudić, B.D. and MAKAROV, S.E. (2013): One hundred millipede species in Serbia (Arthropoda: Myriapoda: Diplopoda). Archives of Biological Sciences, Belgrade 65 (4): 1559-1578.

[2] AnTiĆ, D.Ž., TOMiĆ, V.T., ĆURČIĆ, B.P.M., ĆURČIĆ, S.B., STAMENKOVIĆ, S.P., LuČić, L.R. and MAKARov, S.E. (2014): Genus Belbogosoma Ćurčić and Makarov, 2008, with descriptions of new troglobitic species from east Serbia, Balkan Peninsula (Diplopoda: Chordeumatida: Anthroleucosomatidae). Archives of Biological Sciences, Belgrade 66 (2): 907-918.

[3] AtTEMs, C. (1903): Beiträge zur Myriopodenkunde. Zoologishe Jahrbücher, Abteilung für Systematic 18: 63-154.

[4] Attems, C. (1929): Die Myriopodenfauna von Albanien und Jugoslawien. Zoologishe Jahrbücher (Systematik) 56 (3/4): 173-356.

[5] ĆURČIĆ, B.P.M. and MAKAROV, S.E. (1997): Diversification and biogeographic features of millipedes in Serbia, Yugoslavia (Diplopoda). Entomologica scandinavica, Suppl., Lund 51: 191-197.

[6] ĆURČIĆ, B.P.M. and MAKAROV, S.E. (1998): New report on soil-dwelling millipedes (Diplopoda, Myriapoda) from West Serbia. Archives of Biological Sciences, Belgrade 50: $5 \mathrm{P}-6 \mathrm{P}$.

[7] Enghoff, H. and Kime, R.D. (ed.): (2013): Fauna Europaea. Myriapoda. Fauna Europaea, version 2.6.2, available from http://www.faunaeur.org

[8] Korsós, Z. and READ, H.D. (1994): Revision of the horvathi group and description of a new species of Cylindroiulus (Diplopoda: Julidae). Journal of Natural History 28: 841852.

[9] MRŠIĆ, N. (1985): Contribution to the knowledge of Diplopods (Myriapoda: Diplopoda) of Serbia. I. Bulletin of Natural History Museum, Belgrade 40 (B): 143-168.

[10] READ, H.J. (2007): The millipede genus Cylindroiulus Verhoeff, 1894 in north-west Spain and northern Portugal: Recent records and descriptions of four new species (Diplopoda, Julida, Julidae). Graellsia 63 (2): 279-294.

[11] SchubarT, O. (1934): Tausendfubler oder Myriapoda. I: Diplopoda. Tierwelt Deutschlands, Jena: 1-457.

[12] Strasser, K. (1971): Diplopoda. Catalogus Faunae Jugoslaviae. Consilium Academiarum Scientiarum Rei Publicae Socialisticae Foederative Jugoslaviae. Academia Scientiarum et Artium Slovenica III/5: 1-50.

[13] Strasser, K. (1971a): Uber Diplopoden Jugoslawiens. Senckenbergiana biologica, Frankfurt 52: 313-343.

[14] VerhoefF, K.W. (1905): Anmerkungen yu den Tafelwerken von C. L. Koch, die Myriapoden und A. Berlese (F. Silvestri) Acari, Miriapodi e Scorpioni italiani. Zur Klärung einiger Diplopoden-Gruppen und über einen neuen Iuliden. Notizen zu einigen neueren Arbeiten von C. Attems und über zwei neue Polybothrus. Zoologischer Anzeiger 29 (16): 497-514.

[15] VuČKOVIĆ, Z. (1956): Prilog proučavanju faune stonoga (Myriapoda) severne Srbije i Vojvodine. Zbornik Matice Srpske, Serija prirodnih nauka 10: 1-7. 